\title{
A New flavonol glycoside from the flowers of Moringa pterygosperma
}

\author{
${ }^{1}$ Rohit Kumar Bargah, ${ }^{2}$ Chinmoyee Das* \\ ${ }^{1,2}$ Principal, Govt. College Sargawn, Bilaspur (C.G.), India - 495001
}

\begin{abstract}
A new flavonol glycoside was isolated from the flowers of Moringa pterygosperma (Moringeaeae). It has been isolated from the ethyl acetate extract of ethanolic extract of the flowers of plant. The structure of this compound was determined as Rhamnetin 3-0- (2" galloyl) - $\beta$-D-galacto pyranosyl 4- $\beta$-D-xyloside on the basis of $U V, I R,{ }^{1} H N M R, C^{13}-N M R$ and mass spectral data.
\end{abstract}

Keywords: Flavonol glycoside, Moringa pterygosperma, Moringaecae, rhamnetin, ethanolic extract.

\section{Introduction}

The plant Moringa pterygosperma classified into Moringaecae family is widely distributed in Bangladesh, Shrilanka, South east Asia, India, Nepal and Pakistan. Moringa pterygosperma Commonly known as Drumstick. It is commonly used in Indian folk medicine ${ }^{1-2}$ for the treatment of various illness. It is grows to 10-15 meter high and rapidly growing tree. The flower 1.5 to $2.0 \mathrm{~cm}$ long. This species have been well studied because most of them present medicinal and nutritional properties..$^{3-4}$ It leaves are used in antibacterial ${ }^{5}$, antitumor ${ }^{6}$, hypotensive ${ }^{7}$, antiulcer ${ }^{8}$, anticancer ${ }^{9}$, and antioxidant ${ }^{10}$. From time to time different compounds are isolated from various parts of this plant such as kaempferol, rhammetin, quercetin from flower, vanillin, $\beta$ sitosterol octacosanoic acid from stembark and amino acid, lucine, phenyl alanine from leaves.

In the present paper, we herein report the desirably the structure of a new Rhamnetin 3-0-(2" galloyl) $\beta$-D-galacto pyranosiyle $4-\beta$-D-xyloside from the flowers of Moringa pterygosperma. This plant was the first phytochemical report the isolation and structural elucidation of new flavonol glycoside.

\subsection{Apparatus:}

\section{Experimental}

TLC was carried out on silica gel $\mathrm{G}$ with the following solvent system. (a) Benzene : Etylacetate $(9: 1 \mathrm{v} / \mathrm{v})$. (b) Benzene: Ethylacetate $\mathrm{H}_{2} \mathrm{O}(7: 2: 1, \mathrm{v} / \mathrm{v})$. Preaprative TLC and flash $\mathrm{CC}$ was also done on silica gel G. UV were recorded in $\mathrm{MeOH}$ and after addition of usual shift reagents, IR as $\mathrm{KBr}$ disks. ${ }^{1} \mathrm{HNMR}$ spectra were recorded at $300 \mathrm{MHz}$ in $\mathrm{CDCl}_{3}$ soln using TMS as internal standard. $\mathrm{C}^{13} \mathrm{NMR}$ spectra were measured at $300 \mathrm{MHz}$ in $\mathrm{CDCl}_{3}+\mathrm{DMSO}$ with the same internal standard. GCMS solution system EI was measured on a micro mass spectrometer

\subsection{Plant material:}

The flowers of Moringa pterygosperma were collected during Nov. - Dec. 2008 at Deverikhurd, Bilaspur (C.G.) India. A voucher specimen is deposited at the CDRI, Allahabad.

\subsection{Extraction and isolation:}

The air dried and powdered flower plants of Moringa pterygosperma $1 \mathrm{~kg}$. were extracted with hexane and further extracted with $80 \%$ boiling ethanol in a soxhlet extractor for $72 \mathrm{hr}$. The extracted was evaporated in a rotary evaporator and dried under vacuum.

The conc. ethanolic extract was suspended into distilled water and further extracted with hexane, benzene, chloroform, ethyl accetale and n-butanol. The ethyl acetate soluble fraction $(1.26 \mathrm{~g})$ was subjected to chromatography on column of silica gel (60-120 mesh, Merck) gave a compound-1 and eluted with Benzene: chloroform $(9: 1, \mathrm{v} / \mathrm{v})$ solvent system. It was punfied and crystallized from dil. ethanol to give compound (I) as yellow amorphous powder. (5.9 $\mathrm{gm})$.

\subsection{Characterisation of the new Compound -1}

Yellow amorphous powder; Homogeneous on TLC, Rf 0.47, 0.18, 0.40; Found C=53.58\%, H-4.67\%, calculated for $\mathrm{C}_{34} \mathrm{H}_{34} \mathrm{O}_{20} \mathrm{C}=53.54 \%, \mathrm{H}=4.46 \%$; m.p 199-200 ${ }^{0} \mathrm{C}$;. IR $V_{\max }^{K_{B r}} \mathrm{~cm}^{-1}: 3420,2970,2832,1715-1730$, 1650, 1620, 1520, 1260, 1050, 845, $780 \mathrm{~cm}^{-1} .{ }^{1} \mathrm{H}$ NMR (DMSO-d $\left.600 \mathrm{MHz}\right): 6.30(1 \mathrm{H}, \mathrm{d}, 2.10 \mathrm{~Hz}, \mathrm{H}-6), 6.60$ $(1 \mathrm{H}, \mathrm{d}, 2.1 \mathrm{~Hz}, \mathrm{H}-8), 8.10\left(1 \mathrm{H}, \mathrm{d}, 9.0 \mathrm{~Hz}, \mathrm{H}-2^{\prime}\right), 7.10\left(1 \mathrm{H}, \mathrm{d}, 9.6 \mathrm{~Hz}, \mathrm{H}-5^{`}\right) 8.10\left(1 \mathrm{H}, \mathrm{d}, 9.0 \mathrm{~Hz}, \mathrm{H}-6^{\prime}\right)$, galactose $\left(1 \mathrm{H}, \mathrm{d}, 8.0 \mathrm{~Hz}, \mathrm{H}-2{ }^{\prime \prime}\right), 3.44$ (1H,d, H-2“), 3.28 (1H, d H-3“), 3.12 (1H,d, H-4“), 3.39 (1H,d, H-5“), 3.48, 3.54 
(2H,dd, 7.1, 11.2 Hz, H-6“), galloyl 6.92 (1H,s, H-2“'), 6.90 (1H,s, H-6“'), xylose 4.78 (1H,s,H-1“”, 6.8

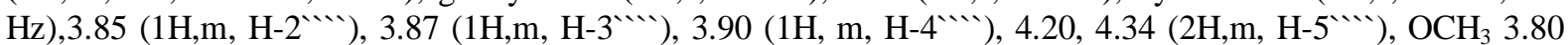
$(3 \mathrm{H},) ; \mathrm{C}^{13} \mathrm{NMR}\left(\mathrm{DMSO}-\mathrm{d}_{6}\right): \delta 156.8(\mathrm{C}-2), 133.5(\mathrm{C}-3), 177.6(\mathrm{C}-4), 160.6(\mathrm{C}-5), 97.8(\mathrm{C}-6), 165.0(\mathrm{C}-7) 91.8$ (C-8), 156.5 (C-9), 104.9 (C-10), 121.0 (C-1`), 115.5 (C-2`), 144.6 (C-3`), 148.4 (C-4`), 116.3 (C-5), 121.9 (C6 ), $55.7\left(\mathrm{OCH}_{3}\right)$, galactose $101.3\left(\mathrm{C}-1^{\prime \prime}\right), 73.6\left(\mathrm{C}-2^{\prime \prime}\right), 76.5\left(\mathrm{C}-3^{\prime \prime}\right), 69.8\left(\mathrm{C}-4^{\prime}\right), 76.5\left(\mathrm{C}-5^{\prime \prime}\right), 68.4\left(\mathrm{C}-6{ }^{\prime}\right)$,

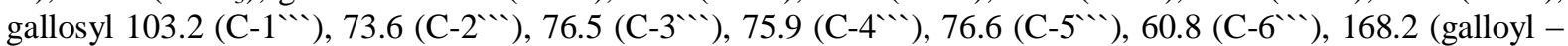

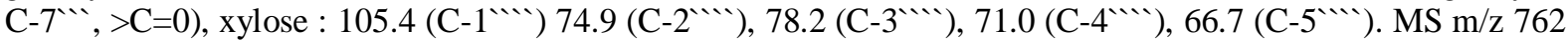
$[\mathrm{M}]^{+}$.

\section{Acid Hydrolysis of flavonol glycoside Compound -1}

$50 \mathrm{mg}$ of compound dissolve in minimum amount of ethanol was refluxed with $70 \% \mathrm{H}_{2} \mathrm{SO}_{4}(50 \mathrm{ml})$ for 3 hrs. The contents were then poured into ice cold $\mathrm{H}_{2} \mathrm{O}$ when a yellowish ppt separated out. This was recrystallized from EtOAc to give aglycone. mp 288, found $\mathrm{C}=60.8 \%, \mathrm{H}=3.8 \%$; calculated for $\mathrm{C}_{16} \mathrm{H}_{12} \mathrm{O}_{7}$ : $\mathrm{C}=60.81, \mathrm{H}=3.78$; $\mathrm{PC}$ of the aq. layer with $\mathrm{n}-\mathrm{BuOH}-\mathrm{HOAC}-\mathrm{H}_{2} \mathrm{O}$ (4:1:5, v/v, spray AHP), showed galactose (Rf 0.35 ), and xylose ( $R f 0.43$ ). The monosachharides were identified as D-galactose and D-xylose by comparison with authentic sample ${ }^{11}$. It gaves positive ferric chloride test. It was identified as rhamnetin on the basis of CoUV, Co-IR, Co-NMR, m.m.p and MS ${ }^{13-15}$.

\section{Result And Discussion}

Compound - 1, mp $199^{0}$, analysed for $\mathrm{C}_{34} \mathrm{H}_{34} \mathrm{O}_{20} ;[\mathrm{M}]^{+} \mathrm{m} / \mathrm{z} 762$ and gave the characteristic colour reaction of flavonol glycoside. On acid hydrolysis ${ }^{12}$, it gave the aglycone rhamnetin (identified by spectral studies and Co-chromatography) with on authentic sample and the sugars D-galactose, D-xylose and gallic acid, identified by pc and $\mathrm{TLC}^{11}$. Methylation of Compound - 1 Followed by hydrolysis gave 5,7,3 - trimethly quercetin showing that the sugars are attached in bioside from at C-3 and C-4 of the aglycone. Permethylated glucoside confirmed the position -3 and 4 to be involved in glycolysation.

The negative ion FAB mass spectrum ${ }^{13}$ of compound -1 showed a $[\mathrm{M}-\mathrm{H}]^{+}$peak at $\mathrm{m} / \mathrm{z} 761$. Its reaction (florescent yellow in $\mathrm{UV}$ with $\mathrm{AlCl}_{3}$ ) and $\mathrm{UV}$ spectral with diagnostic shift reagents suggested the likely presence of 3, 7, 4-trisubstituted flavonol glycoside with hyroxyl group at 5 and 3 position. IR Spectrum of Compound -1 showed strong absorption band at $3420(-\mathrm{OH}), 2970(\mathrm{C}-\mathrm{H}), 1650(\mathrm{C}=\mathrm{C}$, aromatic), $1620(>\mathrm{C}=\mathrm{O})$, 1730-1715 (ester $\mathrm{C}=\mathrm{O}$-streaching); $2832 \quad\left(-\mathrm{OCH}_{3}\right.$ group), 1260 (C-O-C, vibration), $1050,780 \mathrm{~cm}^{-1}$.

The ${ }^{1} \mathrm{HNMR}$ spectrum of compound -1 spectroscopic showed characteristics signal assignable to an anomeric proton $^{14}$ at $5.55(1 \mathrm{H}, \mathrm{d}, \mathrm{J}=8.0 \mathrm{~Hz})$ and $5.70(1 \mathrm{H}, \mathrm{d}, \mathrm{J}=7.3 \mathrm{~Hz})$ ppm these uses attributed to $\mathrm{H}-1^{\prime \prime}$ galactosyl and $\mathrm{H}-1^{\cdots}$ '. $x y$ losyl proton and methylene proton adjacent to an ester group at $\delta 4.24$ $(2 \mathrm{H}, \mathrm{dd}, \mathrm{J}=6,0,11.20 \mathrm{~Hz})$ and $4.43(2 \mathrm{H}, \mathrm{dd}, \mathrm{J}=7.1,11.20 \mathrm{~Hz})$. Attachement of galloyl group through an ester linkage at C-2" in galactose was suggested by the down field shift of 2 “ (5.44) in ${ }^{1} \mathrm{H}$ NMR spectrum. Three oxygenated methane protons at $\delta 3.84(\mathrm{dd}, \mathrm{J}=7.0 \mathrm{~Hz})$ and $3.93(\mathrm{~J}=3.5 \mathrm{~Hz})$ together with anomeric protons at $6.92(2 \mathrm{H}, \mathrm{s})$ group, suggested the presence of a $2{ }^{\prime \prime}$ galloxyl galactoside and 4 -xyloside in compound $-1 .{ }^{13} \mathrm{C}$ NMR spectrum of the glycoside the C-3 carbon shifted upfield by 2.7 ppm and C-2 signal was shifted by 9.2 $\mathrm{ppm}$, the C-4 resonance was also shifted to a down field direction by $1.5 \mathrm{ppm}$ when compound to rhamnetin the magnitude of these glycosylation ${ }^{15}$. The $\mathrm{C}^{13} \mathrm{NMR}$ spectrum of compound indicated that carbon signal (168.2) C-

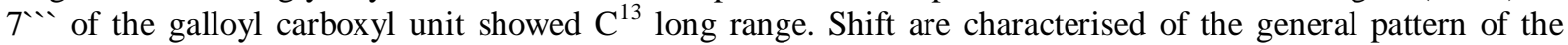
glycosidation shifts when glycosylation these was a were able effect on the C-2 and C-3 thus confirming glycosilation at position 3 and 4 .

\section{Conclusion}

In the present work, the fresh air dried flowers of Moringa pterygosperma was subjected to phytochemical studies. The result of the study showed theat the flowers contain rhamnetin 3-O-(2“'-galloyl)- $\beta$ D-galactopyranosyl-4 - $\beta$-D-xylopyromoside. The structure of the isolated compound was characterized by UV, IR, ${ }^{1} \mathrm{HNMR}, \mathrm{C}^{13} \mathrm{NMr}$ and mass spectrophotometer. This flavonoid glycoside compound (I) was isolated for the first time from a natural product.

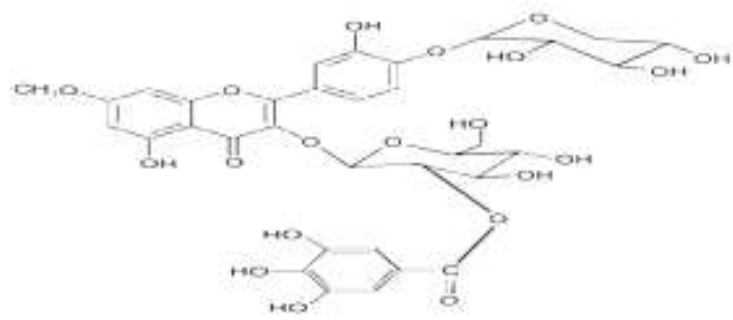

Structure of Compound - 1 
Table $-1: \mathrm{C}^{13}$ and ${ }^{1} \mathrm{H}-\mathrm{NMR}$ Data of compound -1 in DMSO- $\mathrm{d}_{6}$ $(300 \mathrm{MHz}, \delta$ pmm, JHz)

\begin{tabular}{|c|c|c|c|}
\hline Position & $\mathrm{C}^{13}$ & ${ }^{1} \mathrm{H}$ & $\mathrm{JHz}$ \\
\hline \multicolumn{4}{|l|}{ rhamnetin } \\
\hline $\mathrm{C}-2$ & 156.8 & & \\
\hline $\mathrm{C}-3$ & 133.5 & & \\
\hline C-4 & 177.6 & & \\
\hline $\mathrm{C}-5$ & 160.6 & & \\
\hline C-6 & 97.8 & $6.30(1 \mathrm{H}, \mathrm{d})$ & 2.10 \\
\hline C-7 & 165.0 & & \\
\hline $\mathrm{C}-8$ & 91.8 & $6.60(1 \mathrm{H}, \mathrm{d})$ & 2.1 \\
\hline C-9 & 156.5 & & \\
\hline $\mathrm{C}-10$ & 104.9 & & \\
\hline $\mathrm{C}-1^{\prime}$ & 121.0 & & \\
\hline $\mathrm{C}-2$ & 115.5 & $8.10(1 \mathrm{H}, \mathrm{d})$ & 9.0 \\
\hline $\mathrm{C}-3$ & 144.6 & & \\
\hline $\mathrm{C}-4$ & 148.4 & & \\
\hline $\mathrm{C}-5$ & 116.3 & $7.10(1 \mathrm{H}, \mathrm{d})$ & 9.6 \\
\hline $\mathrm{C}-6$ & 121.9 & $8.10(1 \mathrm{H}, \mathrm{d})$ & 9.0 \\
\hline $\mathrm{OCH}_{3}$ & 55.7 & $3.80(3 \mathrm{H}, \mathrm{s})$ & \\
\hline golactose $\mathrm{C}-1^{\prime \prime}$ & 101.3 & $5.55(1 \mathrm{H}, \mathrm{d})$ & 8.0 \\
\hline $\mathrm{C}-2^{\prime \prime}$ & 73.6 & $3.44(1 \mathrm{H}, \mathrm{d})$ & - \\
\hline $\mathrm{C}-3^{\prime \prime}$ & 76.5 & $3.28(1 \mathrm{H}, \mathrm{d})$ & - \\
\hline $\mathrm{C}-4{ }^{\prime \prime}$ & 69.8 & $3.12(1 \mathrm{H}, \mathrm{d})$ & - \\
\hline $\mathrm{C}-5^{\prime \prime}$ & 76.5 & $3.39(1 \mathrm{H}, \mathrm{d})$ & - \\
\hline$C-6 "$ & 68.4 & $3.48,3.54(2 \mathrm{H}, \mathrm{dd})$ & $7.1,11.2$ \\
\hline galloyl C-1“" & 103.2 & - & \\
\hline $\mathrm{C}-2 \lll$ & 73.6 & $6.92(1 \mathrm{H}, \mathrm{s})$ & \\
\hline $\mathrm{C}-3{ }^{\prime \prime}$ & 76.5 & & \\
\hline C-4"' & 75.9 & & \\
\hline $\mathrm{C}-5^{\prime \prime}$ & 76.6 & & \\
\hline C-6"' & 60.8 & $6.90(1 \mathrm{H}, \mathrm{s})$ & \\
\hline$>\mathrm{C}=\mathrm{O}, \mathrm{C}-7^{\cdots}$ & 168.2 & & \\
\hline xylose C-1“'” & 105.4 & $4.78(1 \mathrm{H}, \mathrm{s})$ & 6.8 \\
\hline $\mathrm{C}-2{ }^{\prime \prime}$ & 74.9 & $3.85(1 \mathrm{H}, \mathrm{m})$ & - \\
\hline $\mathrm{C}-3^{\cdots} \cdots$ & 78.2 & $3.87(1 \mathrm{H}, \mathrm{m})$ & - \\
\hline C-4“" & 71.0 & $3.90(1 \mathrm{H}, \mathrm{m})$ & - \\
\hline $\mathrm{C}-5^{\cdots}$ & 66.7 & $4.20,4.23(2 \mathrm{H})$, & - \\
\hline
\end{tabular}

\section{Acknowledgments}

Express my sincere thanks to Dr. Arvind Sharma, Principal college of science for providing me guidance and necessary research facilities to carry out this work at the college laboratory. I also thanks Mr. N.C. Harshavardhan Technical Manager ISO : Cell and Mrs. Rekha Parik, Scientist, IICT, Hydrabad.

\section{References}

[1] R.N. Chopara, I.C. Chopara, K.L. Hande and L.D. Kapur, Indigenris drugs of India W.N. Dhar \& Sons : Calcutta, 98,499, 1958.

[2] H. Itokawo, F. Hiranarayan and A. Mitta, Indinesian Medicinal Plants 58-62 (1990).

[3] A. Rao Ivan, Medicinal Plant of the World, New Jersey, 238 (1999)

[4] K.T. Mahmood, T. Mugal and I.U Haq, J. Pharm. Sci \& Res. vol.2 (11), 775-781, (2010).

[5] P. Napolean, J.Anitha and R.R. Emilin, Current Biotica, 3 (1) : $33-37$ (2009).

[6] B.N., Dhawan, M.P. Dubey, N. Mehrotra, and J.S. Tonden, Indian J. Exp. Biol, 594-604 (1980).

[7] S. Faizi, B.S. Siddaqui, R. Saleem, K. Aftab, F. Shaheen, A.H. Gilani, Planta Medica 64: 225-228 (1998).

[8] S.K. Pal, P.K. Mukherjee and B.P. Saha, Phytother Res. 9 (6), 463-465(1995).

[9] A.P. Guevara, C. Vargas, H. Sakurai, Y. Fujiwara, K. Hashimoto, T. Mauka, Mutation Res, 440 (2). $181-188$ (1999).

[10] P. Siddhuraju and K. Becker, J. Agric. Food. Chem. 51 (8), 2144-2155 (2003).

[11] R.L. Whistler and M.L. Wolfrom; Methods Carbohydrate Chem. 1, 102 (1962).

[12] S. Hakomori, J. Bio chem., 55, 205 (1964).

[13] K.R. Markham, H. Geiger, ${ }^{1} \mathrm{H}$ Nuclear Magnetic Resonance Spectroscopy of flavonoids and their glycosides in Hexadeuterodimethyl sulphoxide, Chapman and Hall, 441-497 (1994).

[14] T.J. Mabry, K.R. Markham, M.B. Thomes, The systematic identification of flavonoid, and edn. Springer Verbag, New York (1970).

[15] K.R. Markham, H. Geiger, The flavonoids Advances in Research since 1986, Chapman and Hall, London (1994). 